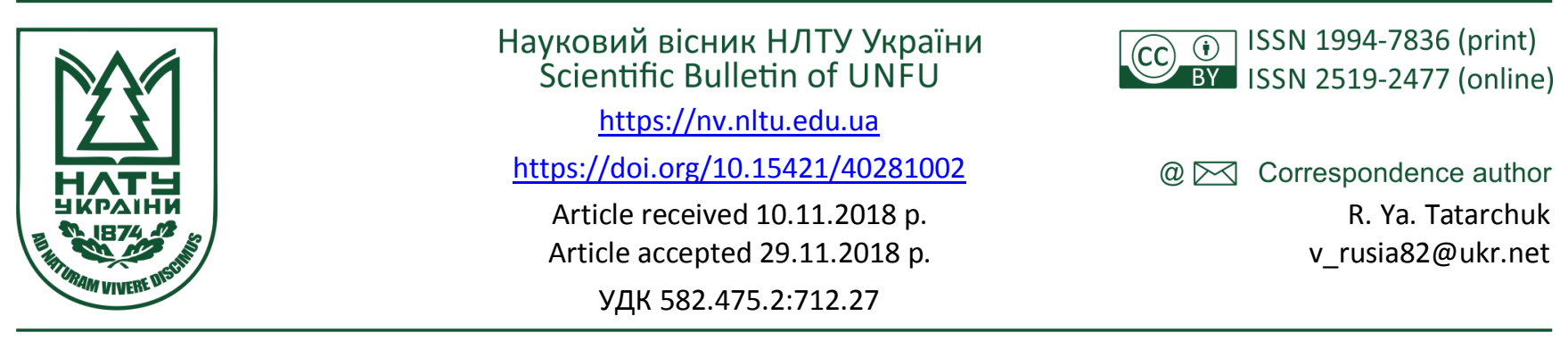

С. Б. Ковалевський ${ }^{1}$ Р. Я. Татарчук ${ }^{2}$

${ }^{1}$ Національний університет біоресурсів і природокористування України, м. Київ, Украӥна

${ }^{2}$ ВП НУБіП Украӥни "Боярський коледж екології і природних ресурсів", м. Боярка, Україна

\title{
КУЛЬТИВАРИ РОДУ THUJA L. ТА JUNIPERUS L. В КАМ'ЯНИСТИХ САДАХ КИЄВА
}

Наведено результати вивчення інтродукційного потенціалу хвойних рослин роду Thuja L. та Juniperus L. в кам'янистих садах києва. В основу досліджень покладено матеріали обстеження кам'янистих садів м. Києва. Подано асортимент найпоширеніших культиварів та їхню коротку характеристику. Проаналізовано видовий склад існуючих насаджень та перспективу збагачення таксономічного складу кам'янистих садів. Дослідженнями встановлено, що основу видового різноманіття в кам'янистих садах складають вічнозелені рослини, переважно карликових і сланких форм. Колоновидні та конусовидні культивари висотою понад 2 м трапляються у великих за площею кам'янистих садах. Наведено порівняльну характеристику на прикладі кам'янистих композицій НБС ім. М. М. Гришка НАН України. Запропоновано проектні пропозиції використання хвойних рослин у кам'янистих композиціях. Під час підбору рослин враховано їхні декоративні властивості (забарвлення хвої, форму крони), вимоги до інтенсивності сонячного освітлення впродовж дня та грунтових умов. Розроблено модель кам'янистого саду з вічнозелених рослин. Культивари роду Thuja L. та Juniperus L. надають кам'янистому саду неповторної чарівності впродовж року. Окрім цього, поєднання хвойних рослин із камінням має особливий ефект.

Ключові слова: культивар; асортимент; характеристика; хвойні рослини.

Вступ. Кам'янистий сад - відносно новий та перспективний прийом зеленого будівництва, який має безліч переваг: компактність, декоративність та невибагливість. На створення кам'янистих садів не витрачають значні кошти, що економічно виправдано, оскільки немає потреби в щорічному доповненню таксономічного складу, і до того ж дає змогу на невеликій площі демонструвати значну кількість рослин, розкривати їхню неповторність і привертати увагу відвідувачів. Вдало підібраний асортимент хвойних рослин для створення кам'янистих садів не лише зменшує витрати на догляд, але й дає змогу зберігати декоративність впродовж року.

Матеріали та методика дослідження. Метою роботи є вивчення видового складу та використання перспективних декоративних рослин у кам'янистих садах києва. Роботу виконували способом маршрутних обстежень 3 визначення таксономічного складу деревних, кущових та квіткових рослин.

Найбільшу увагу приділено поширенню культиварів роду Thuja L. та Juniperus L. в кам'янистих садах києва. Для аналізу таксономічного складу обрано 20 дослідних ділянок, які відрізнялись розмірами, характером рельєфу, особливістю композиційного рішення, грунтовими умовами. Дослідження проводили в насадженнях різного функціонального призначення (НЗК - насадження загального призначення, НОК - насадження обмеженого користування, НСП - насадження спеціального призначення). Визначення видового складу прово- дили за "Определителем высших растений Украины" (Dobrochaeva et al., 1999).

Результати дослідження. За результатами досліджень встановлено, що найбільшу кількість кам'янистих експозицій зібрано в Національному ботанічному саду ім. М. М. Гришка НАН України. Деякі з них створено досить давно, інші - впродовж останніх років. Кожна 3 ділянок має свою назву: "Гірський сад", "Корейський традиційний сад", "Японський сад", "Ділянка тібетської природної культури", "Кам'янистий сад", "Гравійний сад", "Австрійський альпійський сад", "Пори року", "Колекція декоративних сосен".

Враховуючи колекційну мету тієї чи іншої ділянки, таксономічний склад насаджень істотно відрізняється один від одного. Наприклад, "Австрійський альпійський сад" представлено двома експозиціями. У першій експозиції змодельовано верхній пояс, субальпійський пояс та альпійські луки гірського масиву Ракс північних Альп поблизу Відня. Флора Австрійських Альп представлена Pinus nigra Arn., різновидами Pinus mugo Turra, Juniperus communis L., Juniperus sibirica Burgsd. та альпійськими луговими травами. Нижня експозиція представлена ботанічною колекцією альпійських рослин, створеною за систематичним принципом (рис. 1).

Колекційно-експозиційну ділянку "Гравійний сад" створено впродовж 2007-2010 рр. з метою рекультивації території з будівельним сміттям. На ділянці зростає 19 видів і 20 сортів рослин. "Гравійний сад" належить

Інформація про авторів:

Ковалевський Сергій Борисович, д-р с.-г. наук, професор, кафедра ботаніки, дендрології та лісової селекції.

Email: s.kovalevsky@ukr.net

Татарчук Руслана Ярославівна, здобувач, кафедра ботаніки, дендрології та лісової селекції. Email: v_rusia82@ukr.net

Цитування за ДСтУ: Ковалевський С. Б., Татарчук Р. Я. Культивари роду Thuja L. та Juniperus L. в кам'янистих садах Києва. Науковий вісник НЛтУ України. 2018, т. 28, № 10. С. 13-17.

Citation APA: Kovalevskii, S. B., \& Tatarchuk, R. Ya. (2018). Cultivars of the genus Thuja L. and Juniperus L. in the rocky gardens of Kiev. Scientific Bulletin of UNFU, 28(10), 13-17. https://doi.org/10.15421/40281002 
до садів із мінімальним доглядом. Тут використано декілька видів гравійної відсипки різного кольору і невибагливі до родючості грунту рослини переважно із зеленим та сизим забарвленням хвої: Picea abies 'Nidiformis', Juniperus squamata 'Blue Carpet', Picea pungens 'Glauca Globosa', Thuja occidentalis 'Woodwardii'.

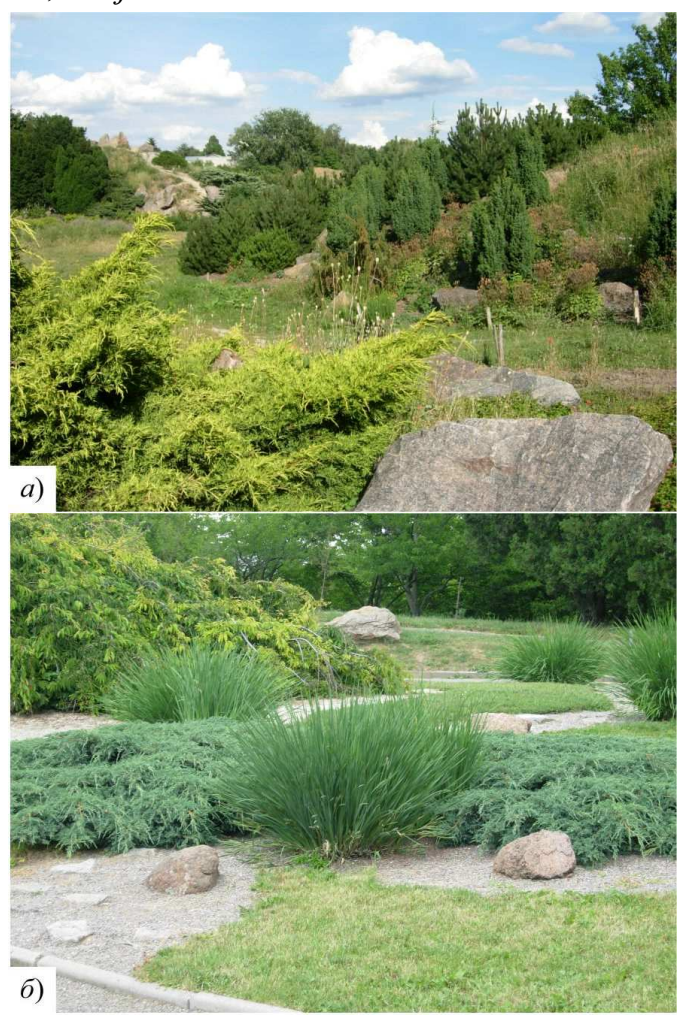

Рис. 1. Представники роду Juniperus L. в кам'янистих композиціях НБС ім. М. М. Гришка НАН України: а) "Австрійський альпійський сад"; б) "Гравійний сад"

Враховуючи невеликий досвід створення кам'янистих садів у вітчизняній практиці, сьогодні актуальною $є$ проблема підбору асортименту декоративних форм деревних та кущових рослин. Від вдалого підбору та умілого їх розміщення значно залежить художнє оформлення саду.

За величиною щорічного приросту хвойні рослини поділяють на 5 груп: повнорослі (приріст за рік становить 30 см), середньорослі (15-30 cм/рік), карликові (8$15 \mathrm{~cm} /$ рік), мініатюрні (3-8 cм/рік), мікроскопічні (приріст менше 1-3 см/рік). Саме останні три категорії хвойних рослин рекомендовано використовувати в кам'янистих садах.

Асортимент хвойних рослин для кам'янистих садів надзвичайно великий (Kolesnikov, 1958, 1974; Limarenko \& Paleeva, 2005; Lypa, Ivchenko \& Reshetniak, 1993), тому наведемо характеристику лише культиварів роду Thuja L. та Juniperus L. (таблиця). Таксономічний склад перспективних рослин для кам'янистих садів представлено двома родами Thuja L. та Juniperus L., до яких належать три види роду Thuja L. та 9 видів роду Juniperus L. Аналізуючи дані таблиці, можна стверджувати, що найбільше культиварів належить Thuja occidentalis L. (24 шт.) та Juniperus horizontalis Moench. (17 шт.). Найменше представників у Thuja plicata Donn ex D. Don. (4 шт.) та Juniperus procumbens (Siebold ex Endl.) Miq. (1 шт.).

Під час підбору хвойних рослин у кам'янистих композиціях враховують такі принципи: екологічний, типологічний (фітоценотичний), систематичний (філогенетичний) та художньо-декоративний (фізіономічний). Декоративні властивості хвойних рослин дають змогу створювати 3 них різноманітні композиції самостійно або в поєднанні з листяними рослинами (Pushkar, 2004). Найчастіше хвойні композиції в кам'янистих садах створюють за художньо-декоративним принципом, який передбачає знання декоративних особливостей рослин, сезонну та вікову динаміку розвитку.

Таблиця. Культивари роду Thuja L. та Juniperus L., перспективні для кам'янистих садів

\begin{tabular}{|c|c|c|c|c|}
\hline Вид & $\begin{array}{c}\text { Найпоширеніші } \\
\text { культивари }\end{array}$ & $\begin{array}{c}\text { Висота, } \\
\text { м }\end{array}$ & Форма крони & Забарвлення хвої \\
\hline \multicolumn{5}{|c|}{$\begin{array}{c}\text { Відділ Голонасінні - Pinophyta; Клас Хвойні - Pinopsida; Порядок Соснові - Pinales } \\
\text { Родина Кипарисові - Cupresaceae F. Neger; Рід Туя - Thuja L. }\end{array}$} \\
\hline \multirow{24}{*}{$\begin{array}{c}\text { Туя західна } \\
\text { Thuja occidentalis } \mathrm{L} \text {. }\end{array}$} & 'Amber Glow' & $0,8-0,9$ & куляста & золотисто-жовте \\
\hline & 'Anniek' & $0,5-0,8$ & куляста & $\begin{array}{c}\text { лимонно-жовте, взимку набуває } \\
\text { бронзового відтінку }\end{array}$ \\
\hline & 'Aurea Nana' & 0,6 & округла або яйцевидна & золотисте, взимку - зелене \\
\hline & 'Caespitosa' & $0,3-0,4$ & подушковидна & зелене \\
\hline & 'Cloth of Gold' & 2,0 & компактна & $\begin{array}{c}\text { золотисто-жовте, взимку - оранжево-ко- } \\
\text { ричневе }\end{array}$ \\
\hline & 'Compacta' & 2,0 & яйцевидна або конусовидна & яскраво-зелене \\
\hline & 'Danica' & 0,5 & куляста & зелене, взимку -коричнувато-зелене \\
\hline & 'Dumosa' & 1,0 & пірамідальна & зелене \\
\hline & 'Ellwangeriana Aurea' & 1,0 & яйцевидна & золотисто-жовте, взимку бронозово-жовте \\
\hline & 'Ericiodes' & $1,0-1,5$ & ширококонічна & зелене \\
\hline & 'Filiformis' & 1,5 & конусовидна & зелене \\
\hline & 'Globosa' & 1,0 & куляста & світло-зелене, взимку - сіро-зелене \\
\hline & 'Golden Globe' & 0,5 & куляста & золотисте \\
\hline & 'Golden Smaragd' & 2,0 & вузькоколоновидна & жовто-зелене \\
\hline & 'Hoseri' & $0,7-0,9$ & куляста & темно-зелене \\
\hline & 'Hoveyi' & 1,5 & куляста & зелене \\
\hline & 'Little Champion' & 0,5 & карликова округла & зелене \\
\hline & 'Little Giant' & 0,8 & подушковидна & яскраво-зелене, взимку - буро-зелене \\
\hline & 'Lutea Nana' & 2,0 & конусовидна & $\begin{array}{l}\text { влітку золотисто-жовте, } \\
\text { взимку зеленувато-жовте }\end{array}$ \\
\hline & 'Moseri' & $0,5-0,7$ & карликова округла & зелене \\
\hline & 'Recurva Nana' & 1,5 & куляста & зелене \\
\hline & 'Rheingold' & 1,5 & широкопірамідальна & влітку - золотисте, взимку - бронзове \\
\hline & 'Sunkist' & 2,0 & конусовидна & золотисто-жовте \\
\hline & 'Teddy' & $0,3-0,5$ & куляста & зелене \\
\hline
\end{tabular}




\begin{tabular}{|c|c|c|c|c|}
\hline \multirow{4}{*}{$\begin{array}{l}\text { Туя складчаста } \\
\text { Thuja plicata Donn } \\
\text { ex D. Don. }\end{array}$} & 'Can-can' & 1,2 & конусовидна & темно-зелене \\
\hline & 'Forever Goldy' & 2,5 & конусовидна & золотисто-жовте \\
\hline & 'Whipcord' & 1,0 & напівкулевидна плакуча & темно-зелене \\
\hline & 'Zebrina' & 2,5 & ширококонічна & зелене із жовтими полосами \\
\hline \multirow{7}{*}{$\begin{array}{c}\text { Туя східна } \\
\text { Thuja orientalis } \mathrm{L} .\end{array}$} & 'Aurea Nana' & 0,7 & яйцевидна & золотисто-зелене \\
\hline & 'Compacta' & 1,0 & широкоокругла & зелене \\
\hline & 'Elegantissima' & $1,5-2$ & ширококонічна & яскраво-зелене \\
\hline & 'Frenky Boy' & 1,2 & яйцевидна & золотиста, взимку - оранжево-бронзова \\
\hline & 'Justynka' & 1,0 & колоновидна & темно-зелене \\
\hline & 'Madurodam' & 2,5 & яйцевидна & світло-зелене, взимку - бронзове \\
\hline & 'Morgan' & $0,5-0,7$ & овальна & світло-зелене, взимку - бронзове \\
\hline \multicolumn{5}{|c|}{ Рід Ялівець - Juniperus L. } \\
\hline \multirow{5}{*}{$\begin{array}{c}\text { Ялівець віргінський } \\
\text { Juniperus } \\
\text { virginiana } \mathrm{L} .\end{array}$} & 'Blue Arrow' & 2,5 & вузькоколоновидна & блакитне \\
\hline & 'Grey Owl' & 1,0 & розлога & сріблясто-сіре \\
\hline & 'Hetz' & 1,0 & розпростерта & сіро-зелене \\
\hline & 'Skyrocket' & 3,5 & вузькоколоновидна & блакитно-зелене \\
\hline & 'Tripartita' & 2,0 & широкорозпростерта & зелене з блакитним відтінком \\
\hline \multirow{17}{*}{$\begin{array}{c}\text { Ялівець } \\
\text { горизонтальний } \\
\text { Juniperus } \\
\text { horizontalis } \\
\text { Moench. }\end{array}$} & 'Andorra Compact' & 0,4 & подушковидна & сіро-зелене \\
\hline & 'Andorra Variegata' & 0,3 & подушковидна & біло-зелене \\
\hline & 'Bar Harbor' & 0,1 & розлога & блакитно-зелене \\
\hline & 'Blue Chip' & 0,3 & компактна & блакитне \\
\hline & 'Blue Forest' & 0,4 & сланка & сріблясто-блакитне \\
\hline & 'Douglassi' & 0,5 & сланка & сіро-зелене, взимку - бронзове \\
\hline & 'Glauca' & 0,3 & розпростерта & блакитне \\
\hline & 'Golden Carpet' & 0,1 & сланка & зелено-золотисто-жовте \\
\hline & 'Grey Pearl' & 0,3 & розпростерта & сіро-блакитне, взимку бронзове \\
\hline & 'Hughes' & 0,5 & сланка & сріблясто-блакитне \\
\hline & 'Jade River' & 0,1 & сланка & сіро-блакитне \\
\hline & 'Limeglow' & 0,5 & гніздоподібна & золотисто-жовте \\
\hline & 'Monber' & 0,1 & сланка & яскраво-блакитне \\
\hline & 'Prince of Wales' & 0,3 & сланка & блакитне \\
\hline & 'Plumosa' & 0,5 & кулеподібна & сіро-зелене \\
\hline & 'Variegata' & 0,3 & розлога & біло-зелене \\
\hline & 'Wiltonii' & 0,3 & сланка & блакитне \\
\hline \multirow{13}{*}{$\begin{array}{c}\text { Ялівець } \\
\text { 3вичайний } \\
\text { Juniperus } \\
\text { communis L. }\end{array}$} & 'Arnold' & 1,5 & вузьколоновидна & зелене \\
\hline & 'Compressa' & 1,0 & колоновидна & світло-зелене \\
\hline & 'Depressa aurea' & 0,15 & карликова & жовто-зелене \\
\hline & 'Green Carpet' & 0,1 & карликова сланка & світло-зелене \\
\hline & 'Hibernica' & 1,5 & вузькоколоновидна & блакитно-зелене \\
\hline & 'Hibernica Aurea' & 1,3 & конічна & золотисто-жовте \\
\hline & 'Hornibrookii' & 0,6 & сланка & світло-зелене \\
\hline & 'Meyer' & 1,5 & вузькоколоновидна & сріблясто-зелене \\
\hline & 'Nana Aurea' & 0,5 & карликова сланка & світло-жовте \\
\hline & 'Pyramidalis' & 1,5 & колоновидна & зелене \\
\hline & 'Repanda' & $0,3-0,6$ & карликова сланка & сріблясто-зелене \\
\hline & 'Spotty Spreader' & 0,2 & сланка & біло-зелене \\
\hline & 'Suecica Nana' & 1,5 & вузькоколоновидна & блакитно-зелене \\
\hline \multirow{13}{*}{$\begin{array}{l}\text { Ялівець китайський } \\
\text { Juniperus chinen- } \\
\text { sis L. }\end{array}$} & 'Blaauw' & 2,0 & воронкоподібна & сіро-зелене \\
\hline & 'Blue Alps' & 2,0 & розлога & зелено-сріблясто-блакитна \\
\hline & 'Ekspansa Variegata' & 0,3 & розпростерта & жовто-зелене \\
\hline & 'Gold Coast' & $0,5-1,0$ & компактна & золотисто-жовте \\
\hline & 'Hetzii' & 2,0 & розлога & сіро-зелене \\
\hline & 'Monarch' & $1,5-2,0$ & колоновидна & блакитно-зелене \\
\hline & 'Old Gold' & $1,5-2,0$ & компактна & бронзово-жовте \\
\hline & 'Pfitzeriana Spaeth' & 1,2 & сланка & яскраво-зелене \\
\hline & 'Plumosa' & 1,0 & воронковидна & зелене \\
\hline & 'Plumosa Aurea' & $1,0-2,0$ & сланка & золотисто-жовте, взимку бронзове \\
\hline & 'Robusta Green' & 1,5 & вузьколоновидна & блакитно-зелене \\
\hline & 'Spartan' & 3,0 & колоновидна & світло-зелене \\
\hline & 'Stricta' & 1,5 & колоновидна & блакитно-зелене \\
\hline \multirow{11}{*}{$\begin{array}{l}\text { Ялівець } \\
\text { козацький } \\
\text { Juniperus } \\
\text { sabina L. }\end{array}$} & 'Arcadia' & 0,3 & подушковидна & зелене \\
\hline & 'Blaue Donau' & 1,0 & розлога & блакитно-зелене \\
\hline & 'Broadmoor' & 0,3 & широкорозпростерта & зелене \\
\hline & 'Cupressifolia' & 0,5 & розпростерта & блакитно-зелене \\
\hline & 'Femina' & 1,5 & широкорозпростерта & темно-зелене \\
\hline & 'Glauca' & 1,5 & розлога & блакитно-зелене \\
\hline & 'Mas' & 0,5 & широкорозпростерта & сизо-зелене \\
\hline & 'Nana' & 0,8 & карликова & темно-зелене \\
\hline & 'Rockery Gem' & 0,5 & карликова широкорозпростерта & блакитно-зелене \\
\hline & 'Tamariscifolia' & 1,0 & розлога & сизо-зелене \\
\hline & 'Variegata' & 1,0 & широкорозпростерта & біло-зелене \\
\hline $\begin{array}{c}\text { Ялівець лежачий } \\
\text { Juniperus procum- } \\
\text { bens (Siebold ex } \\
\text { Endl.) Miq. }\end{array}$ & 'Nana' & 0,2 & подушковидна & блакитно-зелене \\
\hline
\end{tabular}




\begin{tabular}{|c|c|c|c|c|}
\hline \multirow{9}{*}{$\begin{array}{l}\text { Ялівець лускатий } \\
\text { Juniperus squamata } \\
\text { Buch.-Ham. }\end{array}$} & 'Blue Carpet' & $0,3-0,6$ & сланка & сіро-блакитне \\
\hline & 'Blue Spider' & 0,3 & компактна & сріблясто-блакитне \\
\hline & 'Blue Star' & 0,4 & сланка & біло-блакитне \\
\hline & 'Blue Swede' & $1,2-1,5$ & розлога & блакитно-зелене \\
\hline & 'Dream Joy' & $0,3-0,6$ & подушковидна & зеленувато-жовта \\
\hline & 'Floreant' & 1,0 & компактна & біло-блакитне \\
\hline & 'Holger' & 0,8 & розлога & сизо-зелене \\
\hline & 'Hunnetorp' & 0,5 & розлога & блакитно-зелене \\
\hline & 'Meyeri' & 1,0 & воронковидна & сріблясто-блакитне \\
\hline \multirow{2}{*}{$\begin{array}{c}\text { Ялівець } \\
\text { прибережний } \\
\text { Juniperus conferta } \\
\text { Parl. }\end{array}$} & 'Blue Pacific' & 0,4 & сланка & блакитно-зелене \\
\hline & 'Schlanger' & 0,2 & розлога & темно-зелене \\
\hline \multirow{13}{*}{$\begin{array}{c}\text { Ялівець середній } \\
\text { Пфітцеріана } \\
\text { Juniperus media Pfit- } \\
\text { zeriana } \\
\text { V. D. Dmitriev }\end{array}$} & 'Blue and Gold' & 1,0 & розлога & блакитно-жовте \\
\hline & 'Glauca' & 1,5 & розлога & блакитно-зелене \\
\hline & 'Gold Coast' & 1,0 & компактна & золотисто-жовте \\
\hline & 'Gold Star' & $0,5-1,0$ & компактна & золотисто-жовте \\
\hline & 'Hetzii' & 0,25 & розлога & сіро-блакитне \\
\hline & 'King of Spring' & 0,5 & компактна & жовто-зелене \\
\hline & 'Mint Julep' & 1,0 & розлога & яскраво-зелене \\
\hline & 'Mathot' & 0,5 & розлога & блакитно-зелене \\
\hline & 'Mordigan Gold' & 1,2 & розпростерта & жовто-зелене \\
\hline & 'Old Gold' & 1,5 & розпростерта & золотисто-бронзове \\
\hline & 'Pfitzeriana Aurea' & $1-1,5$ & широкорозлога & золотисто-жовте \\
\hline & 'Pfitzeriana Compacta' & 0,8 & широкорозпростерта & сіро-зелене \\
\hline & 'Pfitzeriana Glauca' & $1,2-1,8$ & розпростерта & сизо-зелене \\
\hline
\end{tabular}

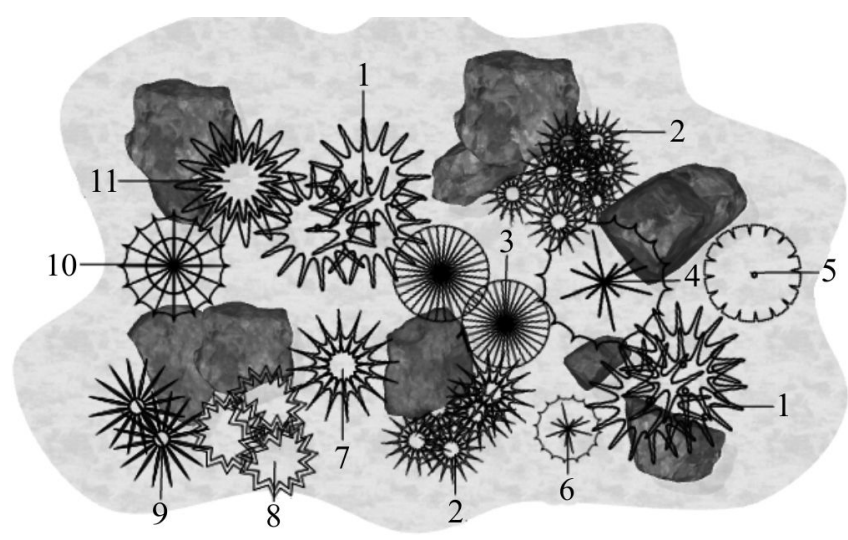

Рис. 2. Модель кам'янистого саду із хвойних рослин: 1) Juniperus sabina L.; 2) Juniperus procumbens 'Nana'; 3) Juniperus communis 'Pyramidalis'; 4) Thuja orientalis 'Morgan'; 5) Thuja occidentalis 'Globosa'; 6) Thuja occidentalis 'Little Giant'; 7) Thuja occidentalis 'Anniek'; 8) Juniperus squamata 'Blue Carpet'; 9) Juniperus chinensis 'Ekspansa Variegata'; 10) Juniperus chinensis 'Gold Coast'

Для створення гармонійних груп із хвойних рослин варто підбирати рослини різні за висотою, забарвленням хвої (світло-зелене та темно-зелене, жовте, жовтозелене, біло-зелене, сизе та ін.), формою крони (рис. 2).

Відстань насаджень між хвойними рослинами в групових композиціях враховують залежно від функціонального та композиційного рішення.

Висновки. Враховуючи велике різноманіття культиварів на сьогодні, наведений асортимент є не повний. Запропоновано перелік хвойних рослин роду Thuja L. та Juniperus L., які найбільше підходять для створення кам'янистих садів. Результати дослідження свідчать, що значна кількість культиварів належить Thuja occidentalis L. та Juniperus horizontalis Moench. Виділено групи хвойних рослин за величиною щорічного приросту. Створено модель невеликого кам'янистого саду із хвойних рослин. При цьому враховано висоту культиварів, форму крони, забарвлення хвої.

\section{Перелік використаних джерел}

Dobrochaeva, D. N., Kotov, M. I., Prokudin, Iu. N., et al. (1999). The determinant of higher plants of Ukraine, (2nd ed.). Kyiv: Fitosotciotcentr. [In Russian].

Kolesnikov, A. I. (1958). Decorative forms of arboreal breeds. Moscow: Ministerstva munitcipalnogo khoziaistva RSFSR. [In Russian].

Kolesnikov, A. I. (1974). Decorative dendrology. Moscow: Lesn. prom-st. [In Russian].

Limarenko, A. Iu., \& Paleeva, T. V. (2005). Decorative trees and bushes. Moscow: AST; St. Petersburg: Sova. [In Russian].

Lypa, O. L., Ivchenko, I. S., \& Reshetniak, T. A. (1993). Identifier of coniferous plants. Kyiv: Vyshcha shk. [In Ukrainian].

Pushkar, V. V. (2004). Conifers in garden and park construction. Kyiv: High school. [In Ukrainian].

\section{С. Б. Ковалевский 1 Р. Я. Татарчук ${ }^{2}$}

${ }^{I}$ Национальный университет биоресурсов и природопользования Украины, г. Киев, Украина ${ }^{2}$ ОП НУБиП Украины "Боярский колледж экологии и природных ресурсов", г. Боярка, Украина

\section{КУЛЬТИВАРЫ РОДА ТНUJA L. И JUNIPERUS L. В КАМЕНИСТЫХ САДАХ Г. КИЕВА}

Приведены результаты изучения интродукционного потенциала хвойных растений рода Thuja L. и Juniperus L. в каменистых садах г. Киева. В основу исследований положены материалы обследования каменистых садов г. Киева. Подано ассортимент самых распространенных культиваров и их краткую характеристику. Проанализированы видовой состав существующих насаждений и перспектива обогащения таксономического состава каменистых садов. Исследованиями установлено, что основу видового разнообразия в каменистых садах составляют вечнозеленые растения, преимущественно карликовых и стелющихся форм. Колоновидные и конусовидные культивары высотой более 2 м встречаются в больших по площади каменистых садах. Приведена сравнительная характеристика на примере каменистых композиций НБС им. Н. Н. Гришко НАН Украины. Представлены проектные предложения использования хвойных растений в каменистых композициях. При подборе растений учтено их декоративные качества (окраска хвои, форма кроны), требования к интенсивности солнечного освещения в течение дня и почвенных условий. Разработана модель каменистого сада с вечнозеленых растений. Культивары 
рода Thuja L. и Juniperus L. предают каменистому саду неповторимого очарования в течение года. Кроме этого сочетания хвойных растений с камнями имеет особый эффект.

Ключевые слова: культивар; ассортимент; характеристика; хвойные растения.

S. B. Kovalevskii ${ }^{1}$, R. Ya. Tatarchuk ${ }^{2}$

${ }^{I}$ National University of Life and Environmental Sciences of Ukraine, Kyiv, Ukraine

${ }^{2}$ Separated subdivision of NULES of Ukraine "Boyarka College of Ecology and Natural Resources", Boyarka, Ukraine

\section{CULTIVARS OF THE GENUS THUJA L. AND JUNIPERUS L. IN THE ROCKY GARDENS OF KIEV}

The rocky garden is a relatively new and perspective green building characterised by many advantages such as compactness, decorativeness, and unpretentiousness. Creation of rocky gardens does not require any special expenses, it is economically justified, since it does not require an annual supplement to the taxonomic composition, and in addition allows a large number of plants to be displayed on a small square reveals their originality and attracts visitors' attention. A well-chosen assortment of coniferous plants for the creation of rocky gardens not only reduces the cost of care, but also allows you to keep decorativeness throughout the year. The purpose of the work is to study the species composition and the use of promising ornamental plants in the rocky gardens of Kyiv, with the greatest attention paid to the spread of cultivars of the genus Thuja L. and Juniperus L. The work was carried out through route surveys to determine the taxonomic composition of tree, bush, and flowering plants. To analyze the taxonomic composition, 20 experimental sites were selected that differed in size, nature of the relief, the peculiarity of the compositional solution, and soil conditions. The research was carried out in plantations of different functional purposes. It was revealed that the largest amount of rocky exposition is collected in M.M. Gryshko National Botanical Garden of the National Academy of Sciences of Ukraine. Taking into account the collectible purpose of a given site, the taxonomic composition of plantations is significantly different from each other. For example, the "Austrian Alpine Garden" is represented by two expositions. In the first exposition, the upper belt, the subAlpine belt and the Alpine meadows of the Raks of the Northern Alps near Vienna are modeled. The lower exposition is represented by a botanical collection of Alpine plants, created on a systematic basis. Given the small experience of creating rocky gardens in domestic practice, the problem of selection of assortment of decorative forms of wood and bush plants is actual today. The decor of the garden depends to a large extent on the successful selection and skilful placement. When selecting coniferous plants in rocky compositions, the following principles are considered: ecological, typological (phytocoenotic), systematic (phylogenetic) and artisticdecorative (physiognomic). The decorative qualities of coniferous plants allow creating a variety of compositions on their own or in combination with deciduous plants. Most often, coniferous compositions in rocky gardens are created by the artistic and decorative principle, which involves knowledge of the decorative features of plants, seasonal and age dynamics of development.

Keywords: cultivar; assortment; characteristics; coniferous plants. 